\title{
Post-disaster recovery: how to encourage the emergency of economic and social dynamics to improve resilience?
}

\author{
Gwenaël Jouannic ${ }^{1}$ a , Denis Crozier ${ }^{2}$, Tran Duc Minh Chloé $^{2}$, Zéhir Kolli $^{1}$, Fabrice Arki $^{1}$, Eric Matagne $^{2}$, Sandrine Arbizzi $^{3}$ \\ and Laetitia Bomperin ${ }^{3}$ \\ ${ }^{1}$ Cerema, Laboratoire de Nancy, 54510 Tomblaine, France \\ ${ }^{2}$ Cerema, Département Villes et Territoires, 44200 Nantes, France \\ ${ }^{3}$ Cerema, Département Risques Eau Construction, 13100 Aix-en-Provence, France
}

\begin{abstract}
The disaster management cycle is made up of three phases: 1) the prevention during the pre-disaster time 2) the crisis management during the disaster then 3) the post-disaster recovery. Both the "pre-disaster" time and the "crisis" are the most studied phases and tap into the main resources and risk management tools. The post-disaster period is complex, poorly understood, least anticipated, and is characterized by the implication of a wide range of people who have a vested interest. In most cases, the collective will is to recover the initial state, without learning from the disaster. Nevertheless, the post-disaster period could be seen as an opportunity to better reorganize the territory to reduce its vulnerability in anticipation of future flood events. To explore this hypothesis, this work consists in analyzing the post-flood phase from a bibliographical work and the detailed study of 3 disaster areas. These results will lead us to better understand the concept of "recovery" in the post-disaster phase.
\end{abstract}

\section{Introduction}

The paper deals with a major challenge of the $21^{\text {st }}$ century which consits in proposing adaptations for more flood resilient future societies. The rising economic cost of floods coupled with demographic increase in flood risk areas is a reality which has been highlighted by the French National Strategy of Flood Risk Management. During the $3^{\text {rd }}$ World Conference on Disaster Risk Reduction in Sendai in March 2015, four priorities for action to take have been defined for 2015-2030 [1]. The fourth priority dealing with the improvement of the disaster responses to "build back better" in recovery phases consists in rehabilitation and reconstruction.

Introducing changes in society is a difficult task in routine situations. In contrast, the "post-disaster" period (Fig. 1) seems to have elements that are apt to call for the implementation of actions to reduce structural vulnerability: political will to act, available funding to renovate the damaged property, media coverage of the crisis [2] and therefore awareness of the reality of the risk at stake. However, the post-disaster phase remains poorly documented and needs to be better understood in the future. Previous studies show that the recovery phase known as "post-disaster" is crucial to reduce the vulnerability of disaster areas $[2,3,4,5]$.

\footnotetext{
a Corresponding author: gwenael.jouannic@ecerema.fr
}

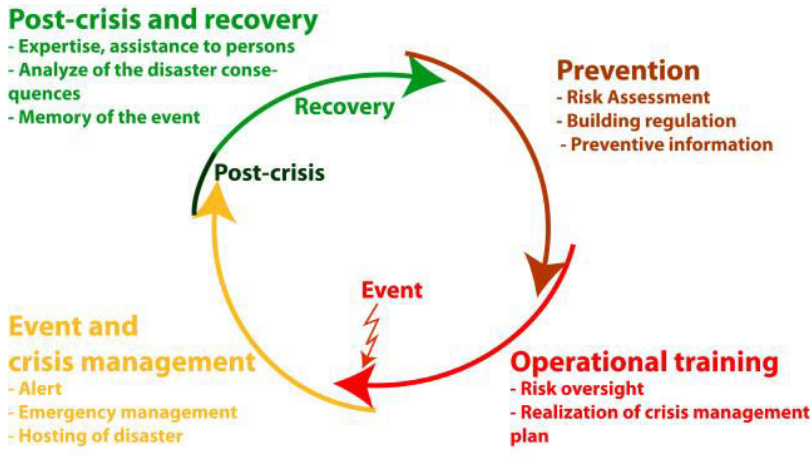

Figure 1. Risk management loop (adapted from Chance and Noury, 2011).

This study questions the opportunities in the reconstruction phase of the territory following a disaster, particularly in terms of reducing vulnerability. In most cases, the collective will is to recover the initial state, and lead to an identical reconstruction of the disaster area (without learning from past mistakes). Nevertheless, the post-disaster period should be seen as an opportunity to better reorganize the territory to reduce its vulnerability in anticipation of future flood events. To explore this hypothesis, this work aims to specify the characteristics of the post-disaster phase in both its temporal development, and through its place and role in flood risk management policy. This work proposes to analyze the post-disaster period through three feedbacks (detailed analysis of disaster areas impacted by floods in the Somme French department in 2001, flash floods in the 
Gard French department in 2002 and floods in SaguenayLac-Saint-Jean in the Canadian province of Quebec in 1996), with a special focus on temporal organization of the post-disaster management and implemented actions. The methodology consists in visiting disaster areas and interviewing actors involved in the reconstruction. This argument finally lead us to explore notions of reconstruction or recovery of disaster areas and question the feasibility, appropriateness and acceptability to reconcile the immediate challenges of a rapid return to normal with the medium-term challenges to reduce vulnerability.

\section{Context of the cases study}

\subsection{Floods of Saguenay-Lac-Saint-Jean in 1996 (Québec)}

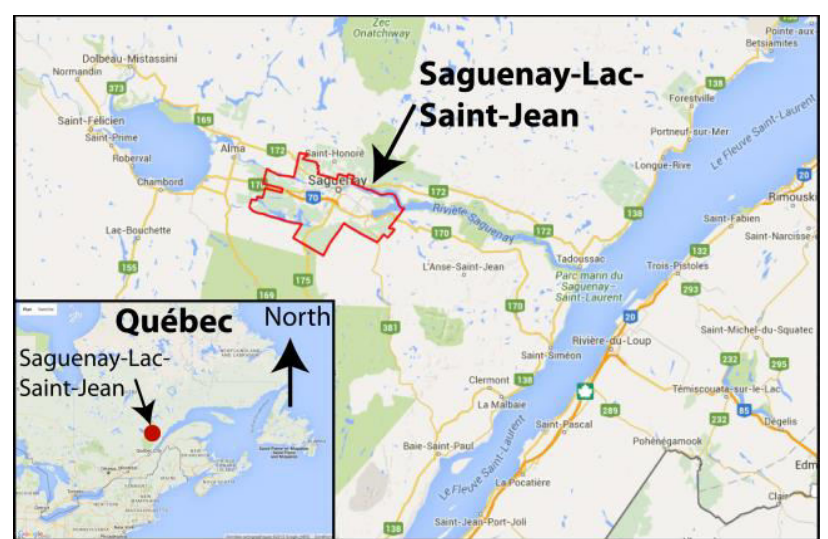

Figure 2. Location of Saguenay-Lac-Saint-Jean (Québec).

The muncipality of Saguenay-Lac-Saint-Jean is located in the Canadian province of Québec along the Saguenay River (Fig. 2). From $19^{\text {th }}$ to $20^{\text {th }}$ July, $174 \mathrm{~mm}$ of rain has been charted in 24 hours and $279 \mathrm{~mm}$ in 48 hours in the southern part of the hydrographic basin of the Saguenay River. The discharge rate of the Kénogami lake (reservoir upstream of Chicoutimi) increased from $200 \mathrm{~m}^{3} / \mathrm{s}$ in a normal situation to $2778 \mathrm{~m}^{3} / \mathrm{s}$, while the evacuation capacity before the first damage to buildings is $940 \mathrm{~m}^{3} / \mathrm{s}$. The evacuation of the Kénogami lake is provided by two dammed rivers: the Rivière-aux-Sables and the Chicoutimi River.

The flood of the Chicoutimi river generated breaks and bypass of dams and bypass of hydraulic infrastructures in Chute Garneau and Pont Arnaud (Fig. 3). The major damages were downstream, resulting in significant changes in landscapes, destruction of public infrastructures, buildings and private properties, and the disruption of drinking water supply at Chicoutimi. Similar damage was observed on the Rivière-aux-Sables (destruction of homes, damage to hydroelectric power plant), and the destruction of bridges.
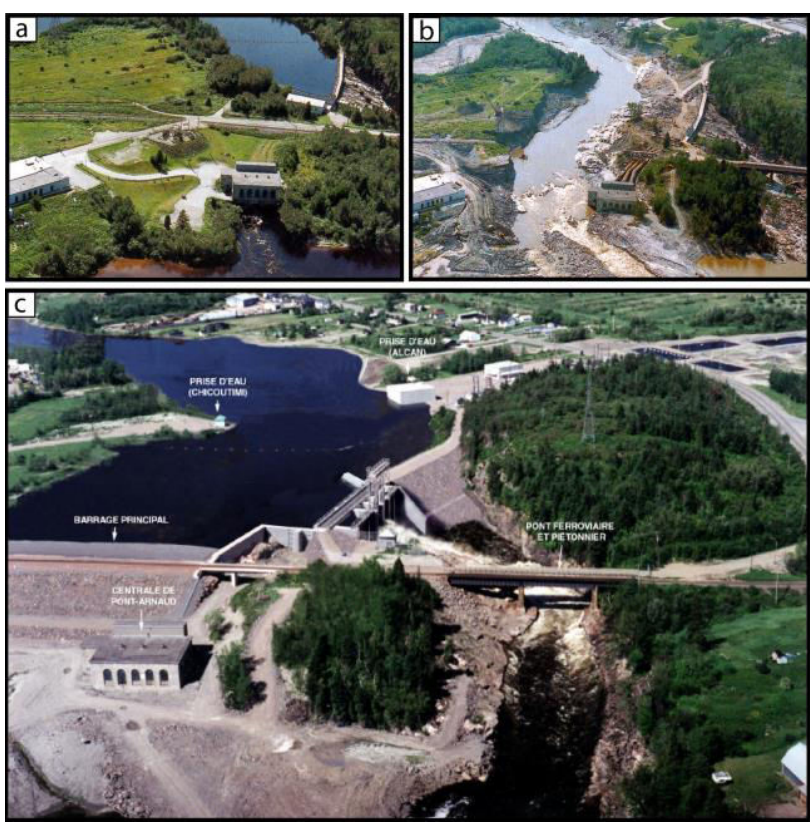

Figure 3. Impact of the floods on the Pont Garneau dam on the Chicoutimi river: a) before the floods; b) during the crisis and c) after the floods (photos: HydroQuébec).

The municipality of La Baie located $10 \mathrm{~km}$ east of Chicoutimi was hit by the overflowing of the Rivière-àMars and the Rivière Ha! Ha!. The consequences of the flood have been increased by breaks of levees and upstream beaver dams. These floods have profoundly changed the profile of the two rivers and the landscape of the two valleys and caused the destruction of several buildings.

Finally, this disaster has highlighted the risk of landslide causing the death of two children in a hillside flank area in the Municipality of La Baie. It took a heavy toll on material losses totting up to about $1 \mathrm{M} \$$ (with 500 homes being destroyed and 1200 damaged), 15000 people were evacuated, and major damage to road and industrial infrastructures were reported.

\subsection{Floods of the Somme in 2001 (France)}

The floods that impacted the Somme French department (Fig. 4) in 2001 lasted 31/2 months. These floods were caused by exceptional rainfall generating the rise of groundwater. 162 municipalities suffered from the floods, 2,800 houses were flooded and more than 1,100 people were evacuated and rehoused. The disaster area chalked up 150 million Euros of damages following this event [6], public infrastructure was also hit and the railway lines were unfit for use for several weeks. 


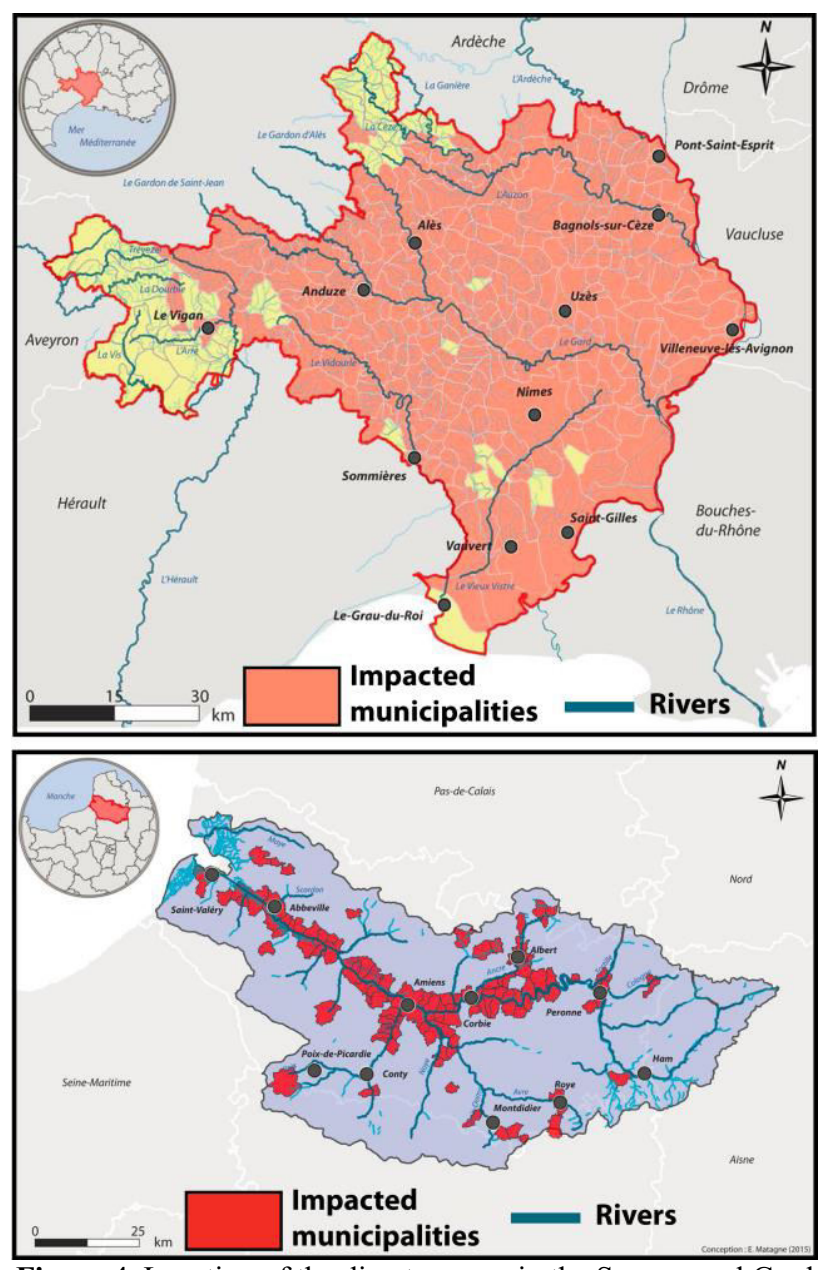

Figure 4. Location of the disaster areas in the Somme and Gard French departments. Sources: BD-CARTHAGE (2013), Open Street Map (2015).

\subsection{Flash floods of the Gard in 2002 (France)}

The Gard French department is subject to seasonal torrential rains (épisodes cévenols) that annually impact the south of France. These phenomena will generate large amounts of water which usually take one or two days. The events of September $8^{\text {th }}$ and $9^{\text {th }}, 2002$ correspond to this type of weather event. More than 5000 square $\mathrm{km}$ (six departments concerned) got over $200 \mathrm{~mm}$ of rain water for $48 \mathrm{~h}$, with a maximum close by $700 \mathrm{~mm}$. In two days, floods killed 23 people in the Gard department only [7].

After the disaster of September $19^{\text {th }}, 295$ of the 353 municipalities on the Gard department have been declared a disaster area (Fig. 4) by the French State [7], with $\sim 7180$ disaster houses. It is estimated that the total damage caused by the floods amounts to $816 \mathrm{M} €$.

\section{Post-disaster feedbacks results}

\subsection{Saguenay-Lac-Saint-Jean}

Major disasters such as the "Saguenay flood" have a national and international media impact that generates a spirit of solidarity. The context of the natural hazard insurance in Québec enforces the government to pay allowances to the victims, which is something that strongly differs from the French regime. In the case of the Saguenay, the Red Cross has mobilized more than 400 million Euros as donation and the budget dedicated to the reconstruction has been allocated directly to the national debt. In reply to this major event, two organisational structures have been created to manage the organisation of the recovery of disaster areas: 1) the secretariat of interdepartmental coordination at the national level, 2) the Bureau de la Reconstruction et de la Relance Economique (BRRE, Office of Reconstruction and Economic Recovery) at the regional level. The BRRE has been established for two years, it has its own funds and a large decision-making autonomy and action. Despite the creation of the BRRE, the reconstruction actions largely differ from one municipality to another.
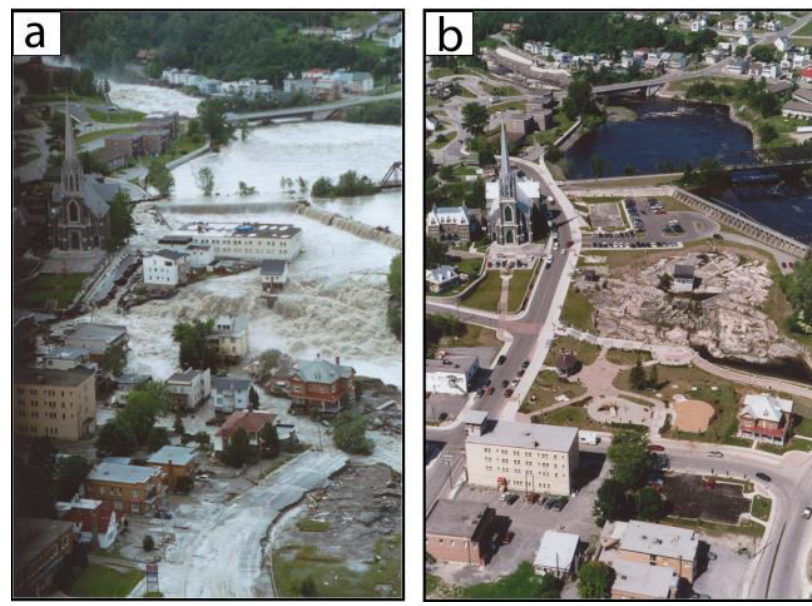

Figure 5. Chicoutimi downtown area a) during the floods of 1996 and b) redevelopment in urban park in memory of the disaster with only the "petite maison blanche" that resist to the torrential floods (photos: Saguenay municipalities).

The changes related to taking into account the risk run in urban planning (essentially relocation issues, reconstruction works and hydraulic redevelopment) are the result of choices made quickly based on criteria defined unilaterally by the public authorities (at the initiative the BRRE) with a specific will not to compound uncertainty to the anxiety inherent in the event. Attempts to initiate a debate on the future of the territory were conducted by the district but without great results because the public authorities and the population were monopolized by the management of disaster or indirectly hit areas (water supply, road access, supplies from the port of raw materials for industrial sites).

A sociological study shows that the negative psychological effects of the Saguenay floods can be largely explained by the destruction (or threat of destruction) of the life projects the victims had made [8]. They had largely invested both financially and emotionally into their residence. 


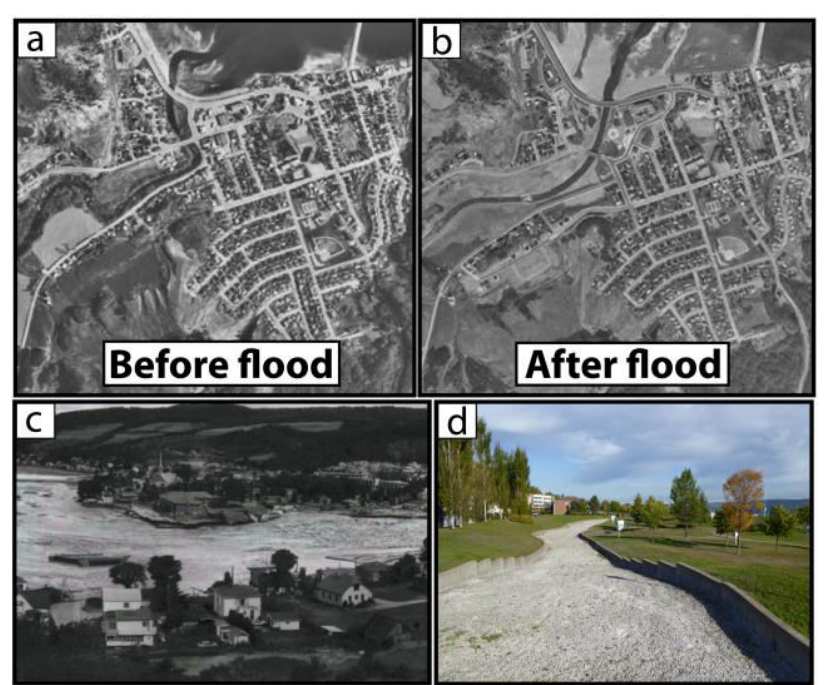

Figure 6. a) Aerial photo of Saint-Alexis district before the 1996 floods, and b) after the floods; c) mouth of the Ha! Ha! river during the floods; d) redevelopment of a park that embodies the old riverbed.

The actors in the reconstruction of Saint-Alexis de La Baie district emphasize the need to come up with postdisaster solutions very quickly. This assessment led the authorities to propose a reconstruction project in a very short time, built on the advice of experts and submitted to the opinion of the population; this new urban plan was finally adopted in a few weeks (Fig. 6). The psychological and social support that has been conducted and the feedbacks from the team who designed the new plan of the Saint-Alexis de La Baie area show the basic need of population to find their bearings again.

This implies the necessity to begin rapid restoration work of the territory (i.e. to erase the traces of the disaster and in particular the removal of debris) before starting the reconstruction. Finally, it means not giving the impression that the disaster reconstruction project is done against the will of the disaster victims which often implies far away relocation of the victims from their previous neighbourhood and no reconstruction of destroyed facilities.

\subsection{Somme department}

The report of the French Senate investigating committee on the flooding of the Somme advocates using "compensation as a lever to develop a genuine policy of risk prevention."

In the case of the Somme, where the risk of flooding due to groundwater rise was not known, priority has been given to understanding of the causes for the flooding of the territory. After the floods of 2001, the Somme watershed committee was created. Its main mission was the improvement of the knowledge of risk run by rising groundwater.

\subsection{The Gard department}

\subsubsection{Sommières}

At Sommières, the particularly violent flood of 2002 followed by other events, led to the housing recommendations concerning the reduction in the process of "unfit for housing" that had been recommended since 1997 on the "Mazère" islet. Moreover, this flood has motivated the choice of relocating several public facilities and a supermarket.

Before the 2002 floods, the hypermarket was located in flooded area on the right bank of the Gard. During the disaster, the building was totally flooded with substantial damages. The relocation of the building was decided and the new building took place outside the flood zone in the town of Villevieille (the plot was purchased by the Gard Departmental Council, see Fig. 7). Work began in February 2008 and ended five months later. The initial plot of the hypermarket had been converted into a parking lot after an agreement was signed between the municipality and the business group.
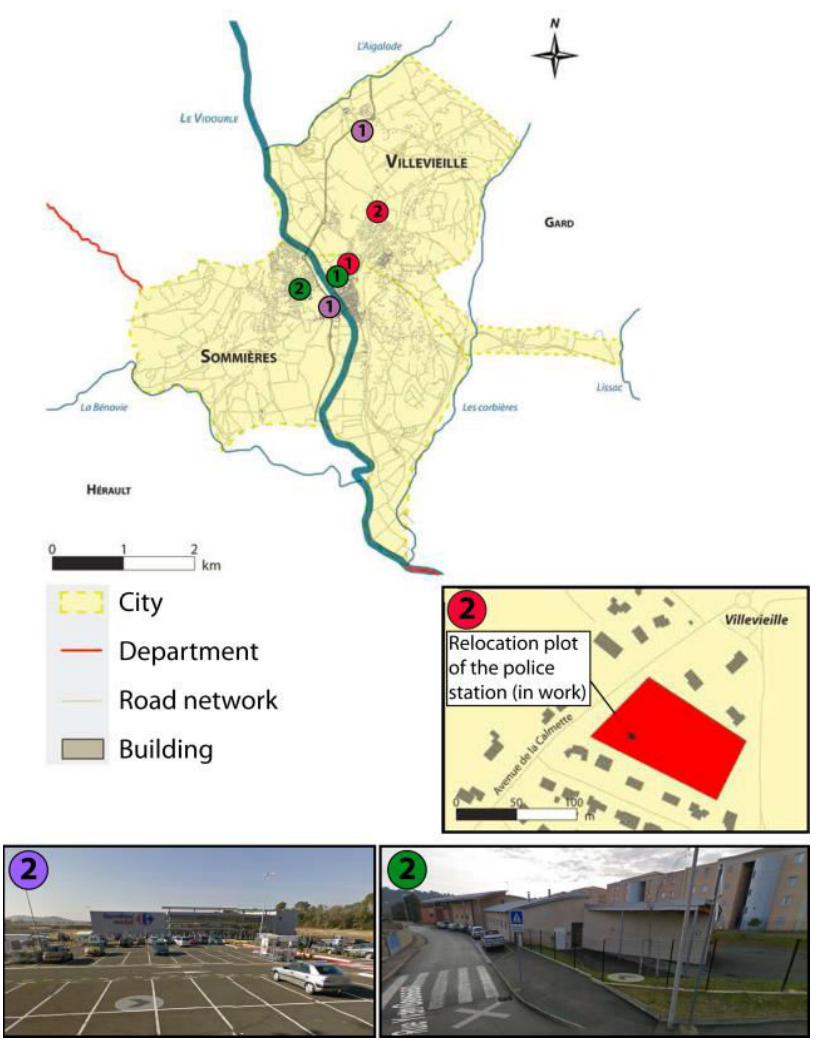

Figure 7. Major relocation of the town of Sommières. Number inside the circles is the location of the building before and during the floods and number 2 is the relocated building after the disaster (red circle: police station; purple circle: supermarket; green circle: school).

An old nursery school (the Condamine school) and a bank suffered significant damage due to the 2002 floods. The ground floor which housed the student had been largely destroyed. Following these events, the regional 
prefect refused to continue to accommodate the students in this building. The reflection which started in the weeks following the disaster led to relocate Condamine nursery school. The new school (Li Passeroun) built on the right bank of the river Gard (outside the flooded area, see Fig. 7) finally opened in December 2008.

One last example is given by the police station which was located on the left bank of the Gard river and was mostly damaged. The relocation project had been discussed since 2002 in order to reconstruct a building in the neighbouring town of Villevieille outside the flood risk area (Fig. 7). However, despite a building permit that had been granted in 2013, the significant costs involved in this relocation slow down the project.

The relocations involved in the municipality of Sommières took several years, although not always effective (as far the police station is concerned), due to difficulties in mobilizing a plot of land outside of the flooded area or to finance the project. A more systematic consideration of the criteria to reduce vulnerability in the choices made during the post-disaster phase therefore requires the implementation of methods and strategies to better meet this goal.

\subsubsection{Collias}

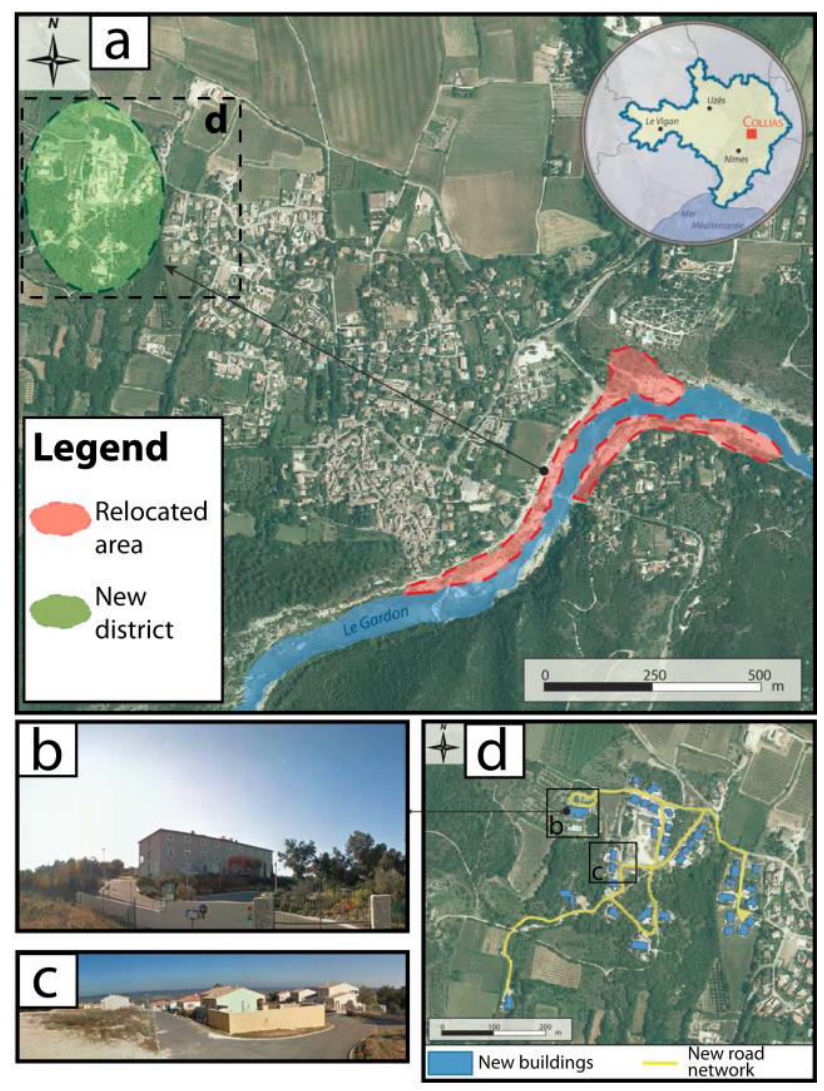

Figure 8. Post-disaster relocation processes in the municipality of Collias (Gard).

The town of Collias crossed by the Gardon is regularly exposed to flash floods causing severe damage to buildings. Floods of $9^{\text {th }}$ September 2002 affected a large part of the population resulting in partial to total destruction of buildings. After this event, the city of Collias has proposed to relocate the houses built in high risk areas on a new common land of 7 ha located outside the flood area (Fig. 8). The aim of this action was to allow the flood victims to rebuild on plot of land provided for this purpose. The price of land has been adapted to respond to the situation $\left(15 € / \mathrm{m}^{2}\right)$, on condition that the plots will not be sold for a minimum of ten years.

The plots of the flood victims have been privately negotiated and listed as unsuitable for development to prevent any new construction on a flood risk area. Finally, 38 of 43 owners have chosen to be relocated. The town of Collias, with the support of the French State, financed the construction of the new housing estate opened on July $7^{\text {th }}, 2005$. During this period, the victims had been relocated by the municipality in available mobile homes to manage the "post-disaster" phase or on their own with friends or family.

In this case, the flooding of 9 and 10 September 2002 in the Gard caused the modification of an urban project on the disaster territory by acting directly on the relocation of buildings. The services offered by the municipality (relocation, amicable acquisition, plot sales prices...) and changes of the regulation framework have contributed to the success of the project. Finally, the disaster has triggered this initiative that is the first of its kind in France. In the case of Collias, the disaster has triggered the realization of a project in "post-disaster" phase, thereby reducing the vulnerability of the victims.

In conclusion, an Interministerial Recovery Committee at the scale of the Gard department coordinated actions with various actors such as insurance companies, local authorities, economic activity and private companies ("Gard floods" fund for rehousing and relocation). The recurrence of flooding forced the actors to develop a form of experience in post-disaster phase management. The adjustments made in the work that was undertaken following the multiple floods made it easier for the population to accept changes.

\section{Post-disaster in the risk management cycle: still a theoretical option}

The disaster management cycle is commonly described in three phases (Fig. 9), 1) the prevention during the pre-disaster time, 2) the crisis management during the disaster, then 3 ) the post-disaster recovery [3, $9,10,11]$. The vast majority of documents (administrative, legislative, public communication, etc.) and actions taken by actors of risk management (national and local administration, water authority, etc.) meet the objectives of the first and second phases:

- The pre-disaster phase focuses on implementing risk prevention measures to prepare the crisis management and reduce the territorial vulnerability. These measures seek to make local residents and 
local authorities aware of the risk to build damage protective structure and to adapt the exposed buildings and infrastructures.

- The disaster phase is characterized by a loss of control. The crisis management seek, therefore, firstly to put people in a safe place and provide shelter for them, then to limit the material damage.

- The post-disaster period, or recovery process, doesn't afford a straightforward definition: Either it means reconstruction of the physical environment and also the social, economic and political aspects? Or it means recovering the initial state or a new stable state? However, the objective is to reach a stable state of emergency after making the system work as best as possible in a makeshift situation.

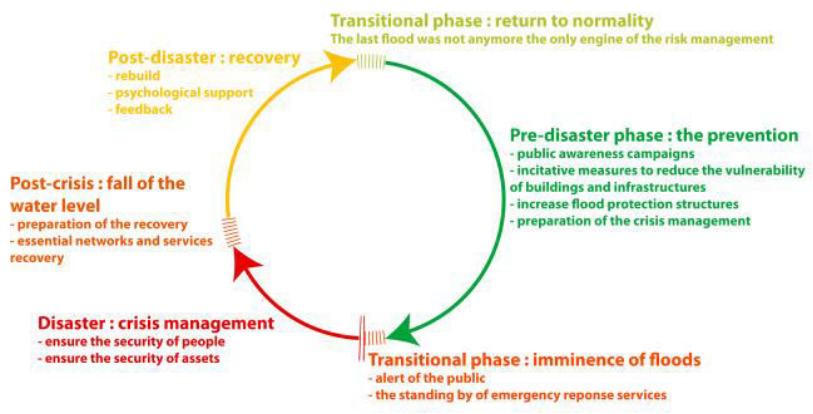

Figure 9. The classical loop of the risk management.

This conceptual model of a cycle matches with the reality of natural hazard. The vulnerability does not disappear after a flood, the territory affected remains potentially exposed to a next flood. Thus the risk management policy should be a repeated and inherent process, in which you gain experience from the successive disasters, in order to reduce the territorial vulnerability. On the other hand, the post-disaster period is frequently presented as the last phase [10]. These observations lead us to distinguish between two different approaches, which serve different objectives: reducing the vulnerability during the "normal functioning" of the territory or managing the present crisis and its consequences to restore normal conditions quickly. This leads us to adjust the model of risk management in which the long term cycle is distinguished from the short term cycle. In this scheme (Fig. 10) which covers most cases, lessons have been learned from the disasters that have highlighted the vulnerability of the territory. The continuous improvement in the process of vulnerability reduction measures focuses on the pre-disaster phase. This point of view suggests that recovery means the restoration of the same situation as before the disaster. This is often the wish of the residents who want to restore their homes, their neighbourhoods and their lives [12]. This pattern is similar to that observed for the floods of the Somme in 2001. But, rebuilding the territory in its original form only helps to maintain the same vulnerability scale as it was before the disaster hit the territory.

In conjunction with the preventive actions, we would suggest that the recovery process could be seen as an opportunity to better reorganize the territory to reduce its vulnerability in anticipation of future flood events. This has been partially the case in the municipality of Collias with the relocation of some houses (Fig. 8), or La Baie, with the relocation of some houses and the restructuring of the river landscape (Fig. 6). The objective of the postdisaster phase would not anymore only be to accelerate the return to normal functioning, even if it means carrying on with the same vulnerabilities. The vulnerability reduction should be taken into account in the choice of the recovery measures undertaken.



Figure 10. Variant loop of the risk management: 2 cycles with different timeframes and purposes

In the second conceptual model (Fig. 11), we still differentiate between two cycles, but the post-disaster phase is therefore now associated with the pre-disaster phase. This new approach which changes the purposes of the recovery process is similar to the "build back better" concept proposed at the third UN World Conference on Disaster Risk Reduction of Sendai [13]. Previous studies $[3,14]$ have already mentioned the existence, during the post-disaster phase, of a tension between two different purposes: recovery and mitigation (structural and nonstructural). From the 1990's, the concepts of vulnerability, then of resilience, have gained in importance. These concepts represent the conviction that a territory has the capacity to reduce the impact of a flood alternatively or in complement with engineering structures of flood protection. Another work argued that "the recovery period offers an opportunity to alter physical development patterns to reduce future hazard vulnerability or find a solution to community problems through reconstruction" [15]. However, the author notes 
that the recovery programs are oriented toward short term relief, with little to do with long term development. The attempts to initiate a debate on the future of SaguenayLac-Saint-Jean's economic recovery ended in failure. In the aftermath of the Saguenay disaster, the affected population had others priorities in mind as the rehousing of victims or the reactivation of networks (roads, electricity, drinking water...), and the sense of urgency of the post-disaster phase was not favourable to deal with the economic issue. Actors in charge of the recovery process argue that recovery can be an opportunity to rebuild less vulnerable houses and infrastructures, without re-designing the whole territory outside the area at risk. It is possible to rebuild differently but the recovery action must remain linked to the flood risk management. This is a trade-off between recovery from the present disaster and protecting the community from the next event.

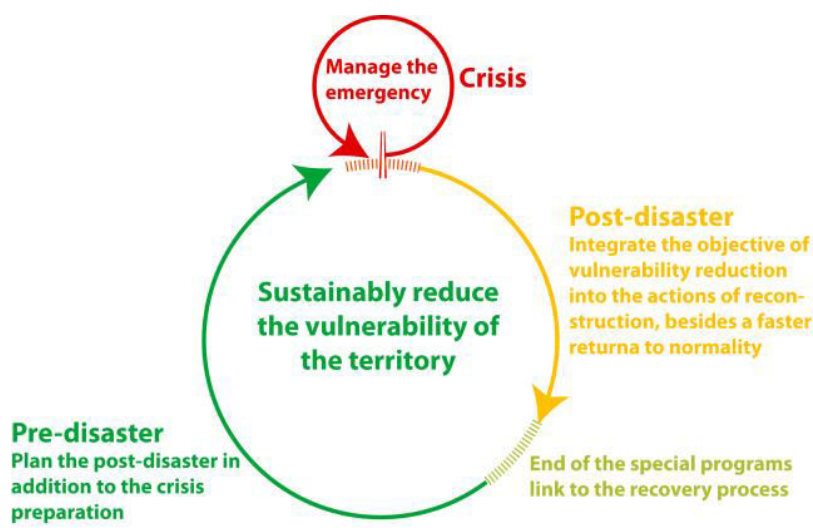

Figure 11. New proposal for the loop of risk management: occasional disturbance in a long-term dynamic.

\section{Post-disaster reconstruction: to coordinate the objectives of both a rapid return to normality and reducing vulnerability factors, what a difficult equation!}

In most cases, the recovery phase after floods does not lead to a measurable reduction of the vulnerability of properties and possessions [16]. The post-disaster feedbacks [2] have shown that apart from relocation, the identical reconstruction prevailed for individual housing. This process is favoured by the regulation (including compensation in case of natural disasters), and the willingness of victims and local stakeholders to quickly find a stable state. The urgency of the recovery is not conducive to major changes on the disaster territory. Relocation requires, in addition to the psychological barrier, a complex and expensive purchase of land.

In most cases, the collective will is to recover the initial state that addresses the need to recreate the conditions of life similar to the "pre-disaster" phase. Rehabilitation and reconstruction is undertaken during a period of strong psychological fragility of the victims
[17] and the climate of the recovery phase is generally confrontational.

In France, damage from natural disasters (floods, earthquakes, landslides...) is compensated for under the "CatNat" system (for "Catastrophes Naturelles"). The Cat-Nat system covers all insured households and assets which are not linked to agricultural production. A fixed percentage of all property damage insurance premiums are deducted to fund a national solidarity fund. The fund is used to compensate victims of natural disasters. A study points out the effectiveness of the protection offered by this system of compensation, nevertheless the authors explain that the principle of national solidarity can lead people to become unaware of their responsibility, without making any difference between the populations living in areas at risk from the population outside areas at risk [18]. This system does not encourage people to take vulnerability reduction measures as far as their property is concerned, neither in the preventive phase nor in the recovery phase of damaged property after a disaster.

Most of the time, major floods events generate postdisaster analysis (feedbacks) from local and national authorities which is part of learning dynamic that aims at reducing the vulnerability of the territory. These approaches do not aim at guiding the recovery project of the territory but at changing 1) national or local policies and 2) flood risk management actions initiated during the prevention phase. Many scientific studies [2, 10, 19, 20], confirmed by our results on the disasters of the Gard in 2002 or in Saguenay-Lac-Saint-Jean in 1996, define the reconstruction phase as a "window of opportunity". The occurrence of a flood destabilizing an entire territory opens opportunities for direct recovery measures, both physical and organizational.

The first effect entailed by this opportunity is to raise the degree of consciousness that makes people aware of the vulnerabilities of the territory in case of a flood. The need of risk culture development increase especially when there are human losses, which calls for the urgency to make changes. The population has to understand that the risk is neither inevitable nor an external constraint to the territory. Our analysis of the post-disaster phase on the 3 cases studies demonstrated that a threshold crossed in terms of material damage (e.g. 500 homes destroyed and 1200 destroyed during the floods of Saguenay) or casualties (23 peoples killed during the flash floods of the Gard) could facilitate acceptance of major changes in post-disaster management. The impact intensity of events has motivated the choice of relocating several public facilities and a supermarket in the city of Sommières (Fig. 7), district relocation in the city of Collias (Fig. 8), or the development of an urban park in memory of the disaster in the city of Chicoutimi (Fig. 5).

During the recovery of a disaster territory, a second opportunity is given to define a large area in which to engage in an overall and coordinated process beyond the 
administrative borders which often split up the area hit by the disaster.

These opportunities can help to act on ongoing projects, by promoting their implementation or modifying the initial project to take into account past disasters or encourage the development of ideas to change the territory. In this sense, a disaster can be used as a catalyst to initiate major changes. The processes of vulnerability reduction established in post-disaster phase already exist but are rare, complex to implement and dependent on local factors. For example, the difference of partnership degree between the local and national authorities on the municipalities of Saint-Alexis de La Baie and Chicoutimi (lower partnership at Chicoutimi) led to differences in the post-disaster urban transformation. The actors in the reconstruction of Saint-Alexis de La Baie designed a new plan of the city with the relocation of the destroyed houses in a new district out of the flooded area (Fig. 6) whereas the municipality of Chicoutimi development an urban park (Fig. 5) on the disaster area but any relocation project.

Today the relevance of reconstruction planning before a disaster occurs remains a scientific hypothesis. Miletti [12] defends the idea, assuming a recovery plan designed in advance would help to reduce the time required for the decision-making process. It would involve the reconstruction planning scheme being already registered in urban planning guidelines well ahead of the disaster.

\section{Conclusions}

Floods feedbacks show the limits of the structural flood control measures (dikes, dams, etc.) to reduce the damages. As a result, the floods management policies are moving towards a complementary approach which favours the incorporation of the vulnerability reduction into the land use, urban and housing policies. Floods feedbacks also show that urban renewal project could be an opportunity to reduce the existing urban areas vulnerability, not only at the component level of individual houses or buildings but also at the urban level. Provided that the actors of the risk, of urban planning and of housing development, collaborate closely together, "the urban renewal brings an alternative beside the regulatory or incentive approaches, sometimes insufficient and partially anchored in the territory" [21]. On this basis, a disaster could be a great opportunity to reduce the vulnerability of territories affected by flooding during the post-disaster recovery. This phase meets some favourable circumstances: the political will for action, available financing for "rehabilitate" the damaged assets and the need to do it, a mediatisation of the crisis, etc. The post-disaster phase could thus be leveraged to realize difficult and expensive plans - blocked or not planned project - or to accelerate programmes underway. The feedbacks on, floods in the Somme French department in 2001, flash floods in the Gard French department in 2002 and floods in Saguenay-Lac-Saint-Jean in the Canadian province of Quebec in 1996, show that the recovery measures, that aim to reduce the vulnerability, can be diversified: relocation, details of construction, watercourse management, landscaping, adaptation of predisaster land use as function of risk exposure, etc.

Previous studies showed a growing interest for the post-disaster phase, whether it be to reduce the duration of the crisis phase or to reduce vulnerability to next crises. They also note that the current vulnerability reduction policies prioritized prevention initiative. They recommended therefore anticipating the recovery process before a disaster.

In synthesis of the three case-studies and the literature, we highlighted several key aspects of postdisaster recovery that facilitate the "build back better":

- the existence of a single organisational structure that coordinates the reconstruction measures, manage the organisation of the recovery and reallocate funds on disaster areas (e.g. Office of Reconstruction and Economic Recovery in Quebec, Interministerial Recovery Committee on the Gard department);

- an important issue for human life that can facilitate social acceptance of major changes (e.g. 23 dead in the Gard in 2002);

- the presence of local authorities and policies voluntary and driving force in terms of flood risk culture;

- the existence of a urban renewal dynamic before a flood, the disaster could be the catalyst (window of opportunity) to accelerate and implement a more resilient project (e.g. the "Mazère" islet at Sommières, see 3.3.1);

- involve the population in the reconstruction process which often implies far away relocation of the victims from their previous neighbourhood (e.g. relocation of the Saint-Alexis de La Baie district, Figure 6).

To conclude, we propose a new conceptual model of the risk management cycle that integrate the concepts of reconstruction and recovery to reconcile the immediate challenges of a rapid return to normal with the mediumterm challenges to reduce vulnerability (Fig. 11). The purposes of this new approach are the integration of the "build back better" concept into to post-disaster recovery process. The aim of this model is to serve 2 different objectives:

1. In conjunction with the preventive actions to sustainably reducing the vulnerability during the "normal functioning", we would suggest that the recovery process could be seen as an opportunity to better reorganize the territory to reduce its vulnerability in anticipation of future flood events.

2. Managing the present crisis and its consequences to restore normal conditions quickly. 
The "long-term" feedbacks multiplication, focus on post-disaster recovery strategies and management, would allow us to have the necessary perspective about consequences inherent in choices, in order to make recommendations on post-disaster recovery.

\section{Acknowledgments}

The authors thank Freddy for his help provided on the English syntax.

\section{References}

1. UNISDR (United Nations International Strategy for Disaster Reduction) (2015), Sendai Framework for Disaster Risk Reduction 2015-2030, 37 p.

2. Camp'huis N.-G. and Ledoux B. (2008). Peut-on vraiment reconstruire les mégapoles après une inondation généralisée ? Les leçons de la nouvelleorléans deux ans après ? Annales des mines, 49, 6571.

3. Haas J.E., Kates R.W. and Bowden M.J. (1977). Reconstruction following disaster. The Massachusetts Institute of Technology Press, Massachusetts, $331 \mathrm{p}$.

4. Vinet F., (2007). Approche institutionnelle et contraintes locales de la gestion du risque. Recherches sur le risque inondation en LanguedocRoussillon. Mémoire d'habilitation à diriger des recherches (HDR). Université Paul-Valéry Montpellier III. Montpellier, p.270.

5. Moatty A. (2015). Pour une Géographie des Reconstructions post-catastrophe : Risques, Sociétés et Territoires. Thèse de doctorat. Université PaulValéry Montpellier III. Montpellier, p.489.

6. Lefrou C. and Verrel J.-L. (2001). Les crues du printemps 2001 dans le bassin de la Somme. Nature Sciences et Sociétés, 9(4), 63-67.

7. Huet P., Martin X., Prime J.-L., Foin P., Lourain C., Cannard P. (2003). Retour d'expérience des crues de septembre 2002 dans les départements du Gard, de l'Hérault, du Vaucluse, des Bouches-du-Rhône, de l'Ardèche et de la Drôme. Rapport consolidé de l'Inspection Générale de l'Administration, le Conseil Général des Ponts et Chaussées, le Conseil Général du Génie Rural des eaux et des forêts, l'Inspection Général de l'Environnement, 546 p.

8. Maltais D., Robichaud S., Lalande G. and Simard A. (1998). De la stupeur à l'adaptation: la long parcours des sinistrés. In M.-U. Proulx (dir.), Une région dans la turbulence, Presses de l'Université de Québec, 129-152.

9. Béraud H. (2013). Initier la résilience du service de gestion des dechets aux catastrophes naturelles: le cas des territoires urbains et de l'inondation. Thèse de doctorat, Université Paris-Est, 448 p.
10. Chance H. and Noury M. (2011). La gestion de la post-catastrophe: l'approche française et la stratégie internationale. Les dossiers de l'Institut des Risques Majeurs, $135 \mathrm{p}$.

11. Leone F., Lavigne F., Paris, R., Denain J.-C. and Vinet F. (2011). A spatial analysis of the December 26th, 2004 tsunami-induced damages: Lessons learned for a better risk assessment integrating buildings vulnerability. Applied Geography, 31, 363375 .

12. Mileti D. (1999). Disasters by Design:: A Reassessment of Natural Hazards in the United States. Joseph Henry Press, Washington D.C., 376 p.

13. United Nation Office for Disaster Risk Reduction (2015). Sendai Framework for Disaster Risk Reduction 2015-2030. UNISDR Report, 36 p.

14. Rubin C.B., Saperstein M.D and Barbee D.G. (1985). Community recovery from a major natural disaster. Florida Mental Health Institute Publications, University of Colorado, $285 \mathrm{p}$.

15. Berke P.R., Kartez J., Wenger D. (1993). Recovery after disaster: achieving sustainable development, mitigation and equity. Disasters, 17(2), 93-109.

16. Veyret Y., Laganier R. (2013). Atlas des risques en France, Prévenir les catastrophes naturelles et technologiques. Editions Autrement, Paris, 96 p.

17. de Vanssay B. (2010). La reconstruction développement durable et réduction de la vulnérabilité. Institut des Risques Majeurs, Risques Info, 24, 6-8.

18. Cours des comptes (2012). Les enseignements des inondations de 2010 sur les inondations de 2010 sur le littoral atlantique (Xynthia) et dans le Var. Rapport public thématique, $305 \mathrm{p}$.

19. Akgungor A.C. (2007). La Turquie à l'épreuve des séismes de 1999: une analyse sociopolitique à travers les discours médiatiques post-catastrophes. Thèse de doctorat, Université Pierre Mendès-France Grenoble II, 563 p.

20. Campanella T. (2006). Urban Resilience and the Recovery of New Orleans. Journal of the American Planning Association, 72, 141-146.

21. Ministère de l'Ecologie, de l'Energie, du Développement Durable et de l'Aménagement du Territoire (2008). Réduction de la vulnérabilité aux inondations et valorisation urbaine. Cadre méthodologique pour la conduite d'un diagnostic de quartier. Illustration par l'exemple du quartier du Faubourg à Béziers. Rapport de méthodologie "Risques naturels majeurs", 28 p. 